\title{
PERBANDINGAN RERATA KADAR HbA1c PADA PASIEN DIABETES MELITUS DENGAN NEUROPATI DAN TANPA NEUROPATI SENSORI MOTOR
}

\author{
Jerry Tanhardjo ${ }^{1}$, Rizaldy Taslim Pinzon ${ }^{2}$, Lisa Kurnia Sari ${ }^{2}$ \\ 1Fakultas Kedokteran Universitas Kristen Duta Wacana \\ ${ }^{2}$ Rumah Sakit Bethesda
}

Korespondensi: medidoc2002@yahoo.com

\begin{abstract}
ABSTRAK
Latar Belakang: Neuropati diabetika/polineuropati diabetika ditandai munculnya kehilangan fungsi saraf secara progresif. Komplikasi ini terjadi pada $50 \%$ pasien dengan DM tipe 1 dan 2 . Kadar HbA1c dapat menggambarkan rata-rata kadar glukosa dalam darah selama 2-3 bulan terakhir. Pemeriksaan ini penting pengelolaan pasien DM dalam jangka panjang dan pasien DM dengan perubahan gula darah yang dramatis setiap harinya. Penelitian sebelumnya mengenai HbA1c dan neuropati masih belum jelas.

Tujuan: Penelitian ini bertujuan untuk membandingkan rerata kadar $\mathrm{HbA} 1 \mathrm{c}$ pada pasien DM dengan neuropati dan tanpa neuropati sensori motor.

Metodologi: Penelitian ini adalah penelitian potong lintang. Penelitian dilakukan di RS Bethesda, Yogyakarta. Pengambilan sampel dengan metode consecutive sampling, dengan jumlah sampel sebanyak 64 sampel. Semua sampel dilakukan screening neuropati sensori motor menggunakan Diabetic Neuropathy Examination, Diabetic Neuropathy Symptom, dan Monofilament Test. Sampel terbagi menjadi 2 kelompok : DM Neuropati (DMN) dan DM Tidak Neuropati (DMTN); masing-masing kelompok terdiri dari 32 sampel.

Hasil: Hasil penelitian pada 64 sampel menunjukkan bahwa kelompok DMN memiliki rerata kadar HbA1c $(\% ;$ mean \pm SD) lebih tinggi dibandingkan kelompok $\operatorname{DMTN}(9,61 \pm 2,60$ Vs. 9,05 $\pm 2,35)$. Hasil analisis data menggunakan uji Chi-Square menunjukkan tidak terdapat hubungan bermakna antara rerata kadar HbA1c terhadap neuropati $(\mathrm{p}=0,368)$. Pada penelitian ini didapatkan durasi DM menunjukkan hubungan bermakna terhadap neuropati $(\mathrm{p}=0,006)$.

Kesimpulan: Rerata kadar HbA1c ditemukan lebih tinggi pada pasien DM dengan neuropati sensori motor dibandingkan pada pasien DM tidak neuropati sensori motor, namun secara statistik tidak signifikan.
\end{abstract}

Kata Kunci : HbA1c, neuropati diabetika, durasi DM 


\title{
COMPARASION HbA1C MEAN LEVEL IN DIABETES MELLITUS PATIENT WITH NEUROPATHY AND WITHOUT SENSORY MOTOR NEUROPATHY
}

\author{
Jerry Tanhardjo ${ }^{1}$, Rizaldy Taslim Pinzon ${ }^{2}$, Lisa Kurnia Sari ${ }^{2}$ \\ ${ }_{1}^{1}$ Medical Faculty of Duta Wacana Christian University \\ 2Bethesda Hospital
}

Correspondence: medidoc2002@yahoo.com

\begin{abstract}
Background: Diabetic neuropathy/diabetic polineuropathy is characterised by a progressive loss nerve function. This is most common complication, affecting $50 \%$ patient with type 1 and type $2 \mathrm{DM}$. HbA1c level define the average blood glucose level for last 2-3 month. This is especially valuable when monitoring diabetics whose blood sugars change dramatically from day-to-day and to monitor long-term diabetic control.

Objective: This study was aimed to comparing the HbA1c mean level in diabetic patient with neuropathy and without sensory motor neuropathy.

Methods: This study was an cross-sectional study. This study was performed in Bethesda Hospital, Yogyakarta. Samples were taken with consecutive sampling method with a total sample of 64 samples. All samples were screened for sensory motor neuropathy using Diabetic Neuropathy Examination, Diabetic Neuropathy Symptom, and Monofilament test. Samples divided into 2 group : Neuropathy Diabetic (ND) and Non-Neuropathy Diabetic (NND) ; each group consisted of 32 samples.

Results: The data consist of 64 samples showed that ND group had higher HbA1c mean level (\% ; mean $\pm S D)$ compared to $N N D$ group $(9,61 \pm 2,60$ Vs. 9,05 \pm 2,35). The result of data analysis using Chi-Square test indicated that there was no significant correlation between $H b A 1 c$ mean level to neuropathy $(p=0,368)$. In this study, DM Duration had a significant correlation to neuropathy ( $p=0,006)$.

Conclusion: $H b A 1 c$ mean level was higher in ND patient compared to NND patient without statistically significant.
\end{abstract}

Keywords: $H b A 1 c$, diabetic neuropathy, DM duration 


\section{PENDAHULUAN}

Neuropati diabetika merupakan komplikasi yang paling sering muncul pada pasien diabetes mellitus (DM). Komplikasi ini terjadi pada $50 \%$ pasien dengan DM tipe 1 dan 2. Neuropati diabetika perifer melibatkan tanda dan gejala disfungsi saraf perifer secara progresif pada pasien diabetes setelah eksklusi kemungkinan penyebab lainnya. ${ }^{1}$ Neuropati diabetika sama banyak mengenai wanita dan pria, dan dapat muncul pada segala usia, tetapi akan lebih sering dengan pertambahan usia dan derajat keparahan serta durasi dari diabetes mellitus. ${ }^{2}$

Prevalensi DM di Indonesia mencapai 8,5 juta orang, menduduki urutan ke-7 terbanyak di dunia dan diperkirakan jumlah ini akan naik pada tahun 2035 dengan estimasi prevalensi DM mencapai 14,1 juta orang. ${ }^{3}$ Prevalensi DM di Indonesia khususnya, tertinggi terdapat di D.I. Yogyakarta sebesar 2,6\%. Prevalensi tertinggi pada kelompok usia 55-64 tahun (terdiagnosis $4,8 \%$, terdiagnosis dengan gejala 5,5\%). ${ }^{4}$ Tanda dan gejala neuropati yang timbul sangat bervariasi tergantung pada saraf yang terkena. ${ }^{5}$

Pengukuran HbA1c dapat memberikan gambaran rata-rata kadar glukosa dalam darah selama 2-3 bulan terakhir. Pemeriksaan ini sangat penting untuk pengelolaan pasien DM dalam jangka panjang dan pasien DM dengan perubahan gula darah yang dramatis memerlukan pemeriksaan kadar HbA1c. ${ }^{6}$ Beberapa penelitian menemukan bahwa menurunkan kadar HbA1c akan berhubungan dengan penurunan kejadian komplikasi pada pasien DM. ${ }^{7}$ Penelitian sebelumnya mengenai HbA1c dan neuropati masih belum jelas. Penelitian ini bertujuan untuk membandingkan rerata kadar $\mathrm{HbA} 1 \mathrm{c}$ pada pasien DM dengan neuropati dan tanpa neuropati sensori motor.

\section{DESAIN DAN METODE PENELITIAN}

\section{Subjek Penelitian}

Penelitian ini merupakan penelitian komparatif numerik dengan pendekatan potong lintang. Penelitian ini dilakukan di Yogyakarta, yaitu di Rumah Sakit Bethesda khususnya di Poli Penyakit Dalam dan Poli Saraf pada Februari sampai Juli 2015. Sampel penelitian kali ini adalah pasien DM Tipe 2 yang memeriksakan diri ke Poli Penyakit Dalam atau Poli Saraf RS Bethesda, Yogyakarta selama tahun 2015. Diagnosis DM tipe 2 diambil berdasarkan ketentuan konsensus PERKENI tahun 2011. Sampel dengan kriteria usia $\geq 15-64$ tahun, tanpa gangguan kesadaran atau komunikasi, tidak sedang mendapat terapi TB atau lepra, atau menderita komplikasi lainnya (demensia, gagal ginjal, kanker, stroke). Subjek penelitian diambil dengan metode consecutive sampling, dan didapatkan 64 subjek yang berpartisipasi dalam penelitian ini.

Subjek dibagi menjadi 2 kelompok: DM Neuropati (DMN) dan DM Tidak Neuropati (DMTN). Neuropati ditentukan dengan pemeriksaan Diabetic Neuropathy Symptoms (DNS), Diabetic Neuropathy Examination (DNE), dan Monofilament test yang dilakukan oleh peneliti dibawah pengawasan Dokter Spesialis Saraf. Masing-masing kelompok terdiri dari 32 subjek dan semua subjek diperiksa kadar HbA1c di Laboratorium RS Bethesda Yogyakarta. Inform consent tertulis dan naskah penjelasan penelitian diberikan kepada semua subjek penelitian. Semua protokol penelitian telah disetujui oleh Komisi Etik Fakultas Kedokteran Universitas Kristen Duta Wacana dan RS Bethesda Yogyakarta. 


\section{Instrumen Penelitian}

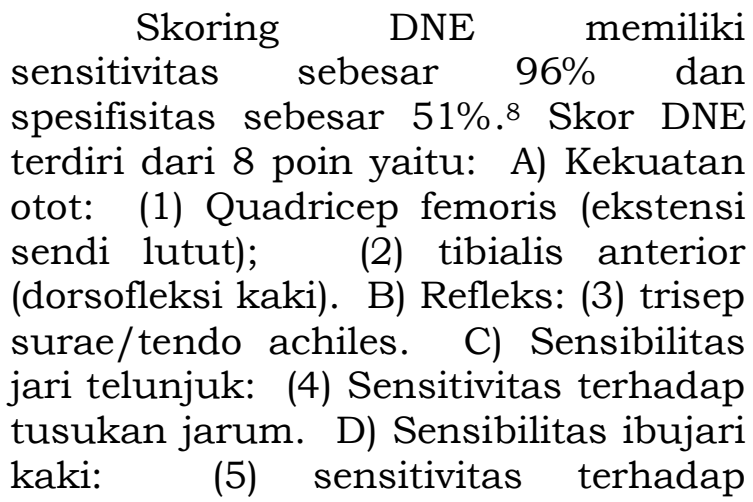
tusukan jarum; (6) sensitivitas terhadap sentuhan; (7) persepsi getar; (8) sensitivitas terhadap posisi sendi. Skor 0 adalah normal; skor 1 defisit ringan atau sedang (kekuatan otot 3-4, refleks dan sensitivitas menurun); skor 2 defisit berat (kekuatan otot 0-2, refleks dan sensitivitas menurun). Nilai maksimal dari 4 macam pemeriksaan tersebut adalah 16. Diagnosis untuk neuropati bila nilai pemeriksaan $>3$ dari 16 nilai tersebut. ${ }^{9}$ Skor DNS memiliki 4 poin untuk menilai gejala untuk menyaring gejala neuropati/polineuropati pada pasien DM. 4 poin tersebut meliputi; (1) Gejala berjalan tidak stabil (butuh bantuan kontrol visual, memberat pada situasi gelap, berjalan seperti orang mabuk, kontak inadekuat dengan lantai); (2) Nyeri neuropatik (Rasa terbakar, tersengat listrik atau rasa tersayat muncul saat beristirahat terutama malam hari, tidak berkaitan dengan latihan, eksklusi intermittenent claudication); (3) Rasa tertusuk dan (4) Parestesia (muncul saat beristirahat atau pada malam hari, distal > proksimal, glove-stocking distribution). Nilai maksimum pemeriksaan tersebut adalah 4. Diagnosis neuropati bila skor 1 atau lebih. ${ }^{9}$ Dalam uji realibilitas neurologikal skor untuk assessment neuropati sensorimotor pada pasien DM tipe 2 mendapatkan skor DNS mempunyai sensitivitas $64,41 \%$ dan spesifisitas $80,95 \% .8$

Monofilament Test, dalam penelitian ini memakai alat yaitu $10 \mathrm{~g}$
Semmes-Weinstein monofilament. Pemeriksaan monofilamen dilakukan di daerah spesifik pada telapak kaki. Setiap tempat pemeriksaan diberikan skor 0 (merasakan sensasi normal, sama seperti saat dicobakan pada dahi atau sternum), skor 0.5 (bila merasakan sensasi abnormal dibandingkan pada dahi atau sternum), skor 1 (bila tidak merasakan sensasi apapun). Bila skor $\geq 3$ dari total maksimal skor 9 maka neuropati diabetika dinyatakan positif. ${ }^{10}$ Monofilament Test didapatkan memiliki nilai sensitivitas sebesar $62,80 \%$ dan spesifisitas sebesar $92,9 \% .9$

\section{Analisis Data}

Data rerata kadar $\mathrm{HbA} 1 \mathrm{c}$ dilakukan perbandingan antara kedua kelompok, lalu dianalisis dengan uji Chi-Square terhadap neuropati. Data variabel lainnya yang diteliti diuji menggunakan uji Chi-Square (jika nominal) dan menggunakan uji Independent t-test (jika numerik) terhadap neuropati. Semua analisis data dilakukan pada tingkat kepercayaan $95 \%$ dengan nilai $a=5 \%$.

\section{HASIL}

Proporsi subjek penelitian DM neuropati didominasi oleh jenis kelamin laki-laki sebesar 20 subjek [laki-laki: $20(62,5 \%)$; perempuan: 12 $(37,5 \%)]$, sedangkan proporsi subjek penelitian DM tidak neuropati seimbang [laki-laki: $16 \quad(50 \%)$; perempuan: $16(50 \%)]$. Rerata durasi DM (tahun) subjek DM neuropati $(11,94 \pm 7,92)$ didapatkan lebih besar dibandingkan rerata durasi DM subjek DM tidak neuropati $(6,69 \pm 6,80)$. Rerata usia (tahun) subjek DM neuropati $(55,16 \pm 7,34)$ didapatkan lebih besar dibandingkan rerata usia subjek DM tidak neuropati (54,06 \pm $6,84)$. 
Tabel 1. Karakteristik Dasar 64 Subjek Penelitian

\begin{tabular}{|c|c|c|c|}
\hline Karakteristik & $\begin{array}{l}\text { Neuropati } \\
(\mathbf{n}=\mathbf{3 2})\end{array}$ & $\begin{array}{c}\text { Tidak } \\
\text { Neuropati } \\
(\mathbf{n}=32)\end{array}$ & $\mathbf{p}$ \\
\hline Usia (Tahun ; mean \pm SD) & $55,16 \pm 7,34$ & $54,06 \pm 6,84$ & 0,540 \\
\hline \multicolumn{4}{|l|}{ Jenis Kelamin } \\
\hline Laki-Laki & $20(62,5 \%)$ & $16(50 \%)$ & \multirow[t]{2}{*}{0,313} \\
\hline Perempuan & $12(37,5 \%)$ & $16(50 \%)$ & \\
\hline Durasi DM (Tahun; mean $\pm \mathrm{SD}$ ) & $11,94 \pm 7,92$ & $6,69 \pm 6,80$ & 0,006 \\
\hline \multicolumn{4}{|l|}{ Hipertensi } \\
\hline $\mathrm{Ya}$ & $13(40,6 \%)$ & $18(56,3 \%)$ & \multirow[t]{2}{*}{0,211} \\
\hline Tidak & $19(59,4 \%)$ & $14(43,8 \%)$ & \\
\hline \multicolumn{4}{|l|}{ Dislipidemia } \\
\hline $\mathrm{Ya}$ & $10(31,3 \%)$ & $17(53,1 \%)$ & \multirow[t]{2}{*}{0,076} \\
\hline Tidak & $22(68,8 \%)$ & $15(46,9 \%)$ & \\
\hline \multicolumn{4}{|l|}{ Obat Hiperglikemik Oral (OHO) } \\
\hline $\mathrm{Ya}$ & $30(93,8 \%)$ & $26(81,3 \%)$ & \multirow[t]{2}{*}{0,257} \\
\hline Tidak & $2(6,3 \%)$ & $6(18,8 \%)$ & \\
\hline \multicolumn{4}{|l|}{ Vitamin C } \\
\hline $\mathrm{Ya}$ & $8(25 \%)$ & $10(31,3 \%)$ & \multirow[t]{2}{*}{0,578} \\
\hline Tidak & $24(75 \%)$ & $22(68,8 \%)$ & \\
\hline \multicolumn{4}{|l|}{ Vitamin E } \\
\hline Ya & $0(0 \%)$ & $3(9,4 \%)$ & \multirow[t]{2}{*}{0,356} \\
\hline Tidak & $32(100 \%)$ & $29(90,6 \%)$ & \\
\hline \multicolumn{4}{|l|}{ Vitamin B } \\
\hline $\mathrm{Ya}$ & $15(46,9 \%)$ & $13(40,6 \%)$ & \multirow[t]{2}{*}{0,614} \\
\hline Tidak & $17(53,1 \%)$ & $19(59,4 \%)$ & \\
\hline \multicolumn{4}{|l|}{ Analgetika Adjuvan } \\
\hline $\mathrm{Ya}$ & $1(3,1 \%)$ & $0(0 \%)$ & \multirow[t]{2}{*}{1,000} \\
\hline Tidak & $31(96,9 \%)$ & $32(100 \%)$ & \\
\hline \multicolumn{4}{|l|}{ Merokok } \\
\hline $\mathrm{Ya}$ & $6(18,8 \%)$ & $5(15,6 \%)$ & \multirow[t]{2}{*}{0,740} \\
\hline Tidak & $26(81,3 \%)$ & $27(84,4 \%)$ & \\
\hline \multicolumn{4}{|l|}{ Insulin } \\
\hline Ya & $9(28,1 \%)$ & $7(21,9 \%)$ & \multirow{2}{*}{0,564} \\
\hline Tidak & $23(71,9 \%)$ & $25(78,1 \%)$ & \\
\hline \multicolumn{4}{|l|}{$\begin{array}{l}\text { Obat Anti Inflamasi Non Steroid } \\
\text { (OAINS) }\end{array}$} \\
\hline $\mathrm{Ya}$ & $10(31,3 \%)$ & $5(15,6 \%)$ & \multirow[t]{2}{*}{0,140} \\
\hline Tidak & $22(68,8 \%)$ & $27(84,4 \%)$ & \\
\hline
\end{tabular}

Tabel 2. Perbandingan Rerata Kadar HbA1c, Durasi DM dan Usia pada Pasien DM dengan Neuropati dan Tidak Neuropati

\begin{tabular}{lccc}
\hline \multicolumn{1}{c}{ Variabel } & $\begin{array}{c}\text { Neuropati } \\
(\mathbf{n = 3 2 )}\end{array}$ & $\begin{array}{c}\text { Tidak Neuropati } \\
(\mathbf{n = 3 2 )}\end{array}$ & $\mathbf{p}$ \\
\hline HbA1c (\% ; mean \pm SD) & $9,61 \pm 2,60$ & $9,05 \pm 2,35$ & 0,368 \\
Durasi DM (Tahun; mean \pm SD) & $11,94 \pm 7,92$ & $6,69 \pm 6,80$ & 0,006 \\
Usia (Tahun; mean \pm SD) & $55,16 \pm 7,34$ & $54,06 \pm 6,84$ & 0,540 \\
\hline
\end{tabular}


Tabel 3. Uji Independent t-test pada HbA1c, Durasi DM dan Usia terhadap Neuropati

\begin{tabular}{ccc}
\hline \multicolumn{1}{c}{ Variabel } & $\mathbf{9 5 \%} \mathbf{C I}$ & $\mathbf{p}$ \\
\hline HbA1c & $-0,678-1,805$ & 0,368 \\
\hline Variabel Perancu & & \\
\hline Durasi DM (Tahun) & $1,560-8,940$ & 0,006 \\
Usia (Tahun) & $-2,455-4,642$ & 0,540 \\
\hline
\end{tabular}

Rerata kadar HbA1c pada pasien DM dengan neuropati $(9,61 \pm$ 2,60) lebih besar dibandingkan dengan rerata kadar $\mathrm{HbA1c}$ pada pasien DM tanpa neuropati $(9,05 \pm$ 2,35). Pada uji t-tidak berpasangan rerata kadar HbA1c ditemukan tidak bermakna secara signifikan terhadap neuropati $(\mathrm{p}=0,368)$. Pada uji t-tidak berpasangan dengan variabel perancu lainnya yaitu durasi DM (tahun) dan usia (tahun) didapatkan durasi DM (tahun) secara statistik bermakna ( $\mathrm{p}=$ 0,006) sedangkan usia (tahun) secara statistik tidak bermakna terhadap neuropati $(p=0,540)$.

Tabel 4. Uji Chi-Square Variabel lainnya Terhadap Neuropati

\begin{tabular}{|c|c|c|c|c|c|}
\hline $\begin{array}{l}\text { Variabel } \\
\text { Perancu }\end{array}$ & $\begin{array}{c}\text { Neuropati } \\
(\mathbf{n}=\mathbf{3 2})\end{array}$ & $\begin{array}{c}\text { Tidak } \\
\text { Neuropati } \\
(n=32)\end{array}$ & OR & 95\% CI & $\mathbf{p}$ \\
\hline $\begin{array}{c}\text { Jenis Kelamin } \\
\text { Laki-Laki } \\
\text { Perempuan }\end{array}$ & $\begin{array}{l}20(62,5 \%) \\
12(37,5 \%)\end{array}$ & $\begin{array}{l}16(50 \%) \\
16(50 \%)\end{array}$ & 1,667 & $0,615-4,513$ & 0,313 \\
\hline Hipertensi & $13(40,6 \%)$ & $18(56,3 \%)$ & 0,532 & $0,197-1,436$ & 0,211 \\
\hline Dislipidemia & $10(31,3 \%)$ & $17(53,1 \%)$ & 0,401 & $0,145-1,112$ & 0,076 \\
\hline $\mathrm{OHO}$ & $30(93,8 \%)$ & $26(81,3 \%)$ & 3,462 & $0,642-18,653$ & 0,257 \\
\hline Vitamin C & $8(25 \%)$ & $10(31,3 \%)$ & 0,733 & $0,245-2,192$ & 0,578 \\
\hline Vitamin $\mathrm{E}$ & $0(0 \%)$ & $3(9,4 \%)$ & 0,233 & $0,011-2,388$ & 0,356 \\
\hline Vitamin B & $15(46,9 \%)$ & $13(40,6 \%)$ & 1,290 & $0,479-3,470$ & 0,614 \\
\hline $\begin{array}{l}\text { Analgetik } \\
\text { Adjuvan }\end{array}$ & $1(3,1 \%)$ & $0(0 \%)$ & 2,066 & $0,144-60,655$ & 1,000 \\
\hline Merokok & $6(18,8 \%)$ & $5(15,6 \%)$ & 1,246 & $0,339-4,588$ & 0,740 \\
\hline Insulin & $9(28,1 \%)$ & $7(21,9 \%)$ & 1,398 & $0,448-4,363$ & 0,564 \\
\hline OAINS & $10(31,3 \%)$ & $5(15,6 \%)$ & 2,455 & $0,730-8,249$ & 0,140 \\
\hline
\end{tabular}

\section{PEMBAHASAN}

Polineuropati distal simetris muncul pada > 90\% pasien DM. ${ }^{11}$ Mekanisme terjadinya neuropati melalui berbagai cara: Jalur Polyol; Aktivitas berlebih Protein Kinase C (PKC); Peningkatan Stress Oksidatif; Mikroangiopati; Penumpukan Advance Glycation End Product (AGEs) dan Interaksi terhadap reseptornya (RAGE). ${ }^{12}$
Rerata HbA1c pada kelompok DM neuropati $(9,61 \pm 2,6 \%)$ dan tanpa neuropati $(9,05 \pm 2,35 \%)$; tidak berhubungan signifikan terhadap neuropati $(p=0,368) ;(95 \% \mathrm{CI}=-0,678$ - 1,805). Berbeda dengan penelitian sebelumnya pada 100 Pasien DM tipe 2, Menunjukkan nilai $\mathrm{p}=0,008$ dengan prevalensi odds ratio sebesar $1,6 \%(95 \% \mathrm{CI}=1,33-1,82) \cdot{ }^{13}$ Hasil yang berbeda juga dilaporkan sebuah penelitian, yaitu rerata $\mathrm{HbA} 1 \mathrm{c}$ pada 
kelompok DM neuropati (9,6 $\pm 2,9 \%)$ dan tanpa neuropati $(7,4 \pm 0,9 \%)$; Rerata HbA1c memiliki hubungan bermakna dengan neuropati $(\mathrm{p}=$ 0,008). ${ }^{14}$

Rerata Durasi DM pada kelompok DM neuropati $(11,94 \pm 7,92)$ dan tanpa neuropati $(6,69 \pm 6,8)$. Durasi DM berhubungan signifikan terhadap neuropati ( $\mathrm{p}=0,006) ;(95 \%$ CI $=1,560-8,940)$. Kondisi hiperglikemia kronis menyebabkan penurunan sekresi insulin atau menurunnya sensitivitas dari insulin. Glukosa yang berlebih akan masuk ke dalam jalur Polyol, sehingga glukosa berubah menjadi sorbitol. Sorbitol yang terbentuk akan menyebabkan stress osmotik intraselular pada sel saraf sehingga dapat menyebabkan kerusakan sel saraf. Dalam mengurangi glukosa intraselular yang tinggi, enzim Aldose reductase mengurangi jumlah glukosa yang masuk ke dalam jalur Polyol, tetapi hal ini juga menyebabkan pengurangan gluthathione yang kemudian meningkatkan produksi dari Advanced Glycation End Product sehingga pada akhirnya akan tetap menimbulkan stress oksidatif pada sel saraf. Semakin lama seseorang menderita DM maka proses ini akan akan berlangsung lebih lama dan terus akan menyebabkan kerusakan lebih lanjut pada sel terutama sel saraf. Sebuah penelitian menunjukkan analisis multivariat hubungan durasi DM signifikan berhubungan dengan derajat keparahan neuropati $(\mathrm{p}=$ 0,030). ${ }^{14}$ Penelitian pada 100 pasien DM ditemukan kadar Oxidative LDL meningkat signifikan pada kelompok DM neuropati. ${ }^{15}$ Studi eksperimental mengkonfirmasi paparan hiperglikemia kronis akan menginduksi stress oksidatif pada sel $\beta$ pancreas. ${ }^{16}$

Rerata Usia pada kelompok DM neuropati $(55,16 \pm 7,34)$ dan tanpa neuropati $(54,06 \pm 6,84)$; tidak berhubungan signifikan terhadap neuropati $(p=0,540)$. Pada sebuah studi epidemiologi potong lintang didapatkan rerata usia pada kelompok DM neuropati $(57,1 \pm 9,7)$ dan tanpa neuropati $(52,5 \pm 10,4)$; $(\mathrm{p}<0,001) \cdot{ }^{17}$ Pada studi potong lintang pada 534 subjek DM tipe 2, didapatkan rerata usia pada kelompok DM neuropati $(69,6 \pm 9,5)$ dan tanpa neuropati $(63,5$ $\pm 9,7) ;(\mathrm{p}<0,001) .18$ Tidak ditemukan hubungan yang signifikan antara jenis kelamin dan neuropati ( $\mathrm{p}=0,313)$. Hampir sama dengan penelitian sebelumnya, pada sebuah studi potong lintang meskipun terdapat perbedaan proporsi jenis kelamin pada kelompok DM neuropati dan tanpa neuropati tetapi jenis kelamin sendiri dikatakan tidak berhubungan signifikan terhadap neuropati (laki laki $3,0 \%$ Vs. perempuan 4,5\%); $\quad(\mathrm{p}=$ 0,099). 18

Hipertensi tidak berhubungan signifikan terhadap neuropati $(\mathrm{p}=$ 0,211 ). Studi prospektif menunjukkan insidensi DM 2/3 lebih tinggi pada pasien dengan hipertensi. ${ }^{19}$ Studi eksperimental pada hewan coba DM hipertensi menunjukkan perubahan morfologi saraf suralis dan sel Schwann mengalami penurunan dibandingkan pada hewan coba DM normotensi $(\mathrm{p}=0,0001) \cdot{ }^{20}$ Dislipidemia tidak berhubungan signifikan terhadap neuropati $(\mathrm{p}=$ 0,076). Kondisi hiperlipidemia bersamaan dengan hiperglikemia kronis akan menimbulkan peningkatan dari ROS yang akan berdampak pada disfunsi sel $\beta$ pankreas kerusakan myelin. ${ }^{21}$ Penggunaan $\mathrm{OHO}$ tidak berhubungan signifikan terhadap neuropati $(\mathrm{p}=$ 0,257). Penelitian oleh American Diabetes Association mengatakan kontrol gula darah (HbA1c $<7 \%$ ) dan konsumsi OHO berhubungan dengan penurunan kejadian komplikasi pasien DM. ${ }^{7}$ Pada penelitian lainnya adanya temuan menarik, yaitu dilaporkan penggunaan $\mathrm{OHO}$ justru menyebabkan penurunan kadar serum vitamin B12 pasien DM sebesar 22-29\%.22 
Sampel pada penelitian kali ini tercatat telah mengkonsumsi vitamin $\mathrm{B}$, vitamin $\mathrm{C}$, vitamin $\mathrm{E}, \mathrm{OHO}$, insulin, analgetika adjuvan dan OAINS sebelumnya baik pada kelompok DMN maupun kelompok DMTN. Penggunaan vitamin B tidak berhubungan signifikan terhadap neuropati $(\mathrm{p}=0,614)$. Vitamin B12 bekerja dalam tubuh dengan memediasi proses enzimatik penting yang berguna untuk myelin, neurotransmitter, dan membran fosfolipid sel. ${ }^{22}$ Penggunaan vitamin $\mathrm{C}$ dan vitamin $\mathrm{E}$ tidak berhubungan signifikan terhadap neuropati: Vit C (p $=0,578)$; Vit $\mathrm{E}(\mathrm{p}=0,356)$. Penelitian dengan hewan coba dilaporkan penggunaan Vit $\mathrm{C}$ dan Vit $\mathrm{E}$ mengurangi gejala diabetes dan risiko komplikasi melalui penurunan kadar stress oksidatif. ${ }^{23}$ Merokok tidak berhubungan signifikan terhadap neuropati $(p=0,740)$. Studi systematic review dan studi meta-analisis didapatkan bahwa merokok meningkatkan risiko dari neuropati diabetik perifer sebesar $42 \% .{ }^{24}$ Penggunaan analgetika adjuvan tidak berhubungan signifikan terhadap neuropati $(\mathrm{p}=1,000)$. Studi kasus mencatat penggunaan amitriptilin topikal $5 \%$ dan $10 \%$ pada pasien DM tipe 2 dengan neuropati dapat menghilangkan nyeri total pada daerah nyeri neuropatik. ${ }^{25}$ Sebuah studi systematic review menunjukkan penggunaan Gabapentin oral pada neuropati diabetik mengurangi 50\% gejala nyeri neuropatik $(\mathrm{RR}=1,6 ; 95 \%$ $\mathrm{CI}=1,3-1,9) .{ }^{26}$

Penggunaan insulin tidak berhubungan signifikan terhadap neuropati $(p=0,564)$. Adanya sebuah laporan kasus mencatat penggunaan Continuous Subcutaneus Insulin Infusion (CSII) selama 6 hari pada pasien DM tipe 2 dengan neuropati menunjukkan perbaikan yang signifikan terhadap nyeri neuropatik. ${ }^{27}$ Pada sebuah studi review dilaporkan penggunaan insulin justru mencetuskan terjadinya "insulin neuritis", yang dimana kondisi ini jarang terjadi sehingga mekanisme dan patofisiologinya belum diketahui dengan jelas. ${ }^{28}$ Penggunaan OAINS tidak berhubungan signifikan terhadap neuropati $(\mathrm{p}=0,140)$. Studi eksperimental terhadap hewan pengerat didapatkan penggunaan meloxicam menunjukkan perbaikan pada aliran darah endoneurial hewan pengerat dengan diabetes. ${ }^{29}$ Meskipun penggunaan OAINS memberikan manfaat pada perbaikan skor neuropati, obat golongan OAINS tidak pernah digunakan sebagai terapi jangka panjang pada pada pasien DM neuropati. 29

Terdapat beberapa kelemahan dalam penelitian ini. Penelitian ini menggunakan metode potong lintang, sehingga variabel yang bermakna (durasi DM) tidak bisa dikatakan sebagai penyebab timbulnya neuropati pada subjek penelitian. Pengambilan sampel dengan metode consecutive sampling dapat memunculkan bias dari peneliti karena tidak melalui proses randomisasi, sehingga sampel dapat dianggap tidak representatif. Pengambilan sampel dilakukan hanya pada satu instansi (RS. Bethesda) sehingga tidak bisa mengetahui kondisi pasien DM pada instansi kesehatan lainnya.

\section{KESIMPULAN}

Rerata kadar HbA1c ditemukan lebih tinggi pada pasien DM dengan neuropati sensori motor dibandingkan pada pasien DM tidak neuropati sensori motor, namun rerata kadar HbA1c tidak berhubungan signifikan terhadap neuropati.

\section{DAFTAR PUSTAKA}

1. Boulton AJ, Vinik AI, Arezzo JC, et al. Diabetic neuropathies : a statement by the American Diabetes Association. Diabetes Care.2005.28(4) : 956-62. 
2. Aaberg et al.Gender differences in the onset of diabetic.2008.

3. International Diabetes Federation. IDF Diabetes Atlas $6^{\text {th }}$ Edition [Online] Available from U R L : http://idf.org/diabetesatlas [Ac cessed 11/12/2014].2013.

4. Riskesdas.Riset Kesehatan Dasar. Jakarta : Badan Penelitian dan Pengembangan Kesehatan Kementrian Kesehatan RI.2013.

5. Dorsey et al. Control of risk factors among people with diagnosed diabetes, by lower extremity disease status. Prev Chronic Dis ; 6(4) : A1 14.2009.

6. Wilson, Denise D.Manual of laboratory \& diagnostic tests. USA : McGraw-Hill. 2008

7. American Diabetes Association. Standart of medical care in diabetes-2014. Diabetes Care. 2014.37(suppl 1) : S14-S80.

8. Asad A, Hamed MA, Khan A, et al. Realibility of the neurological scores of assessment of sensorimotor neuropathy in type 2 diabetics. J Park Med Assoc. 2010.60(3) : 166-70.

9. Jayaprakash $\mathrm{P}$ et al. Validation of bedside methods in evaluation of diabetic peripheral neuropathy. Indian $\mathrm{J}$ Med Res. 2011.pp 645-649.

10. Perkins BA, Olaleye D, Zinman B, et al. Simple screening tests for peripheral neuropathy in the diabetes clinic. Diabetes Care. 200 1.24: 250-6.

11. Schreiber AK, et al.Diabetic Neuropathic pain : physio pathology and treatment. World J Diabetes.2015.6(3): 432-444
12. Alma et al. Abscence of clinical relationship between oxidized low density lipoproteins and diabetic peripheral neuropathy: a case control study. Lipid in health and Disease.13:32. neuropathy. $\mathrm{J}$ Diabetes Complications.2014.22(2) : 83-7.

13. Maidin Tria Sefti, Djallalluddin, Yasmina Alfi.Hubungan kadar $H b A 1 c$ dengan kejadian kaki diabetik pada pasien diabetes melitus. Berkala Kedokteran. 2012. 9(2): 211-217.

14. Harahap, Ervina Susanti. Peranan glycosilated haemoglobin (HbA1c) terhadap derajat neuropati diabetes melitus [Online]. Available from URL : http://etd.ugm.ac.id [Accessed 02/11/2014]. 2013

15. El Erian, A., Anis, M., Ibrahim,H. Oxidative stress marker as early predictors of neuropathy in type 2 diabetes patients. Nature and Science.2015.13(1): 120-126.

16. Oyenihi AB, Ayeleso AO, Mukwevho $\mathrm{E}$ et al. Antioxidant strategies in the management of diabetic neuropathy. Biomed Research International.2015.10.

17. Bansal, et al. Prevalence and risk factors of development of peripheral diabetic neuropathy in type 2 diabetes melitus in tertiary care setting. J Diabetes Invest.2015. 5(6).

18. Han et al.Peripheral neuropathy is associated with insulin resistance independent of metabolic syndrome. Diabetology $\&$ Metabolic Syndrome.2015.7:14. 
19. Franjic B, and Marwick TH. The diabetes, hypertensive heart: epidemiology and mechanism of a very high risk situation. J Hum Hypertens.2009.23: 709-17.

20. Sanada et al. Association of chronic diabetes and hyper tension in sural nerve morphometry: An experimental study. Diabetology \& Metabolic Syndrome.2015.7: 9.

21. S.-H. Ko and B.-Y. Cha. Diabetic Peripheral neuropathy in type 2 diabetes mellitus in Korea. Diabetes and Metabolism Journal.2012. 36(1): 6-12.

22. Kibirige Davis dan Mwebaze Raymond.Vitamin B12 deficiency among patients with.2013.

23. S. H. Salah, H. S. Abdou, and E. A. Abdel Rahim.Modulatory effect of vitamin $A, C$ and $E$ mixtures against tefluthrin pesticide genotoxicity in rats. Pesticide Biochemistry and Physiology.2010. 98(2):191-197.

24. Claire C, Cohen MJ, Eichler F et al. The effect of cigarette smoking on diabetic peripheral neuropathy: a systematic review and meta-analysis. Journal of General Internal Medicine. (2015). 10.

25. Kopsky David dan Hesselink Jan M Keppel.High doses of topical amitriptyline in neuropathic pain: two cases and literature review. Research Gate.2011.2(18).

26. Canadian Agency for Drugs and Technologies in Health. Gabapentin for Adults with Neuropathic Pain : A Review of the Clinical Efficacy and Safety. Available from URL : http://cadth.ca [Accessed 23/07/2015].2015.

27. Kesavadev Jothydev dan Rasheed Sabeer A. Dramatic response of painful peripheral neuropathy with insulin pump in type 2 diabetes; a case report. American Diabetes American Diabetes Association. Available from URL: http:// profesional.diabetes.org [Accessed 23/07/2015].2015.

28. Knopp M, Srikantha M, Rajabally YA. Insulin neuritis and diabetic cachetic neuropathy ; a review. Curr Diabetes Rev.2013.9(3) : 267-74.

29. Wilson NM dan Wright DE. Inflammatory Mediators in Diabetic Neuropathy. J Diabetes Metab. 5(4). diabetes mellitus : is routine screening and supplementation justified?. Journal of Diabetes \& Metabolic Disorders ; 2011. 12 : 17. 